\title{
An Overview of Hepatitis B Virus Surface Antigen Mutant in the Asia Pacific
}

\author{
Shuaibu A Hudu',2, Yasmin A Malik ${ }^{3}$, Mohd T Niazlin', \\ Nabil S. Harmal ${ }^{1,4}$, Zamberi Sekawi ${ }^{1 *}$ \\ ${ }^{1}$ Department of Medical Microbiology and Parasitology, \\ Faculty of Medicine and Health Sciences, Universiti Putra \\ Malaysia. \\ ${ }^{2}$ Department of Pathology and Microbiology, College of \\ Health Sciences, Usmanu Danfodiyo University Sokoto, \\ 840104 Sokoto State, Nigeria. \\ ${ }^{3}$ Department of Clinical Science, Faculty of Medicine and \\ Health Sciences, Universiti Tunku Abdul Rahman, Malaysia. \\ ${ }^{4}$ Department of Medical Microbiology, Faculty of Medicine \\ and Health Sciences, Sana'a University, Sana'a, Yemen.
}

\begin{abstract}
Hepatitis B virus infection is a serious health problem worldwide, and more than 350 million people are chronic carriers, constituting a major global threat. Southeast Asia and the Western Pacific have the highest levels of endemicity in the world, with an estimated seroprevalence ranging between $2 \%$ and $31 \%$. Mutations in the hepatitis $B$ surface antigen (HBsAg) have been reported in many parts of the world but are most common in Asian infants; such mutants have several clinical effects, such as the development of hepatocellular carcinoma. Diagnostic failures by commercial assays have reduced the diagnostic effectiveness of $\mathrm{HBsAg}$ detection. For example the substitution of an amino acid in the major hydrophilic region of the $S$ gene reduces the binding of hepatitis $B$ surface antibodies leading to immune escape. The safety of blood transfusion may be compromised by current screening tests due to escape from being neutralised by antibodies induced by HBsAg mutants, and undetectable levels of viral surface protein. Data on the epidemiology of HBsAg mutation in Asia Pacific are scant; however, this manuscript has reviewed the available information on the epidemiology of HBsAg mutation in Asia Pacific.
\end{abstract}

\section{Introduction}

Asia Pacific is made up of countries in Southeast Asia, East Asia and Oceania (World Macro Regions and Components. 2009). Hepatitis $B$ is a global health problem with about 350 million chronic carriers constituting a major global threat (McMahon, 2005). According to the World Health Organisation (WHO), the western pacific region accounts for about $50 \%$ of the world's chronic hepatitis B infection (Clements et al., 2006). Although hepatitis B global endemicity can be divided into high $(>8 \%)$, intermediate $(2-7 \%)$ and low ( $<2 \%$ ) (Chen Chien-Jen, 2000), there is substantial variation amongst countries of the same continent. Asia Pacific was previously categorised as a high endemic region, but now only a few countries like Vietnam and Laos remain in this category in the region with a prevalence of $8.8 \%$ and

*Corresponding author. Email zamberi@medic.upm.edu.my
$8.7 \%$, respectively (Jutavijittum et al., 2007). Taiwan, Japan, Australia, New Zealand, Thailand and Malaysia were also categorised as intermediate endemic areas, but due to the introduction of vaccination with effective coverage, they are now considered low endemic areas (Chen et al., 2010; Clements et al., 2006; $\mathrm{Ng}$ et al., 2005; Olinger et al., 2008), while China, Indonesia, Pakistan, Singapore and Cambodia are classified as intermediate endemic areas in the region (Abbas et al., 2004; Hong et al., 2010; Lu et al., 2010; Soeung et al., 2009). Although the majority of the countries in Asia Pacific fall within the low endemic $(<2 \%)$ area as shown in figure 1 , the region has a mean prevalence of $3.6 \%$ (SD 2.9), indicating that Asia Pacific is now an intermediate endemic region. Table 1 shows the prevalence of the hepatitis B surface antigen in the general population of some Asia Pacific countries with the highest rates in Vietnam and Laos. Some Asia Pacific countries remain the location for the majority of HBV infections in the world, with Vietnam, South Korea and the Philippines accounting for $75 \%$ of chronic HBV infections worldwide (Clements et al., 2006). The predominant mode of transmission in Asia Pacific is perinatal, and the disease is transmitted vertically during early childhood from the mother to infant (Dwivedi et al., 2011; Shao et al., 2011); however, both horizontal and vertical transmission have been reported in sub-Saharan Africa (Botha et al., 1984).

In Southeast Asia, about 100 million people are chronic carriers of $\mathrm{HBV}$, with an estimated annual mortality of

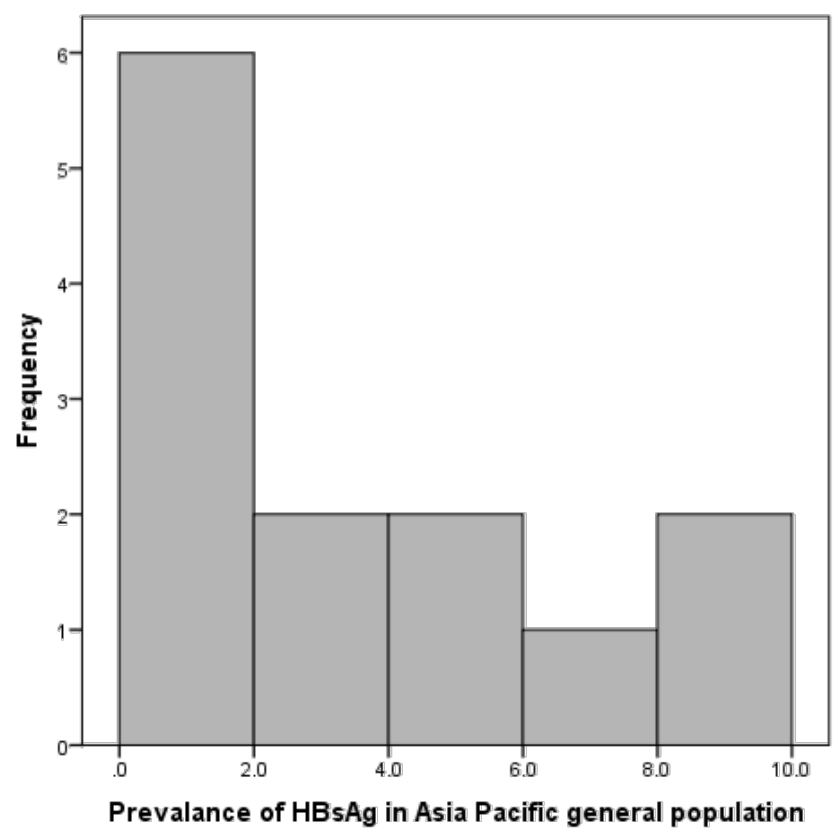

Figure 1. The distribution of hepatitis B surface Antigen positive individuals in the Asia Pacific population. 
Table 1: Prevalence of HBsAg in the Asian general population

\begin{tabular}{lll}
\hline Countries & $\begin{array}{l}\text { HBsAg in general } \\
\text { population (\%) }\end{array}$ & Reference \\
\hline Vietnam & 8.8 & Jutavijittum et al., 2007 \\
Laos & 8.7 & Jutavijittum et al., 2007 \\
China & 7.2 & Liang et al., 2006 \\
Indonesia & 4.6 & WHO 2009 \\
Pakistan & 4 & Abbas et al., 2003 \\
Cambodia & 3.5 & Soeung et al., 2009 \\
Singapore & 2.8 & Hong et al., 2010 \\
Japan & $<2$ & Clements et al., 2006 \\
New Zealand & $<2$ & Clements et al., 2006 \\
Taiwan & 1.1 & Chen et al., 2011 \\
Australia & $0.8-1.1$ & Cowie et al., 2010; O'Sullivan et \\
& & al., 2004 \\
Thailand & 0.7 & Chongsrisawat, 2006 \\
Malaysia & 0.3 & Ng et al., 2005 \\
\hline
\end{tabular}

300,000 , mainly due to hepatocellular carcinoma (HCC) and liver cirrhosis. Therefore, all countries in the Asia Pacific Region view hepatitis B as a serious public health issue and maintain policies, goals and plans, targeted at the prevention and control of hepatitis B. However, in most countries, implementation is not sufficient, sometimes following a series of uncoordinated programmes rather than a consistent strategic approach (WHO 2011).

\section{History of Hepatitis B}

Hepatitis B Virus (HBV) can be dated back to 1967 with the discovery of an unknown antigen in Australia which was recognised to be associated with hepatitis $B$. It was first call "Australia antigen" but later referred to as the hepatitis $B$ surface antigen (HBsAg) (Blumberg B. S., 1967).

\section{Hepatitis B Virus}

Hepatitis $B$ virus is a Hepatotropic DNA virus belonging to the genus Orthohepadnavirus, family of Hepadnaviridae, and is composed of an envelope, a core, a DNA genome, and a viral polymerase. It has a circular form of partially doublestranded DNA that is approximately 3200 nucleotides in length (Lee and Ahn, 2011; Scaglioni, 1996). The full grown, infective virion of HBV is spherical in shape and $42-45 \mathrm{~nm}$ in diameter (Dane particle), meaning that it can be visualised under an electron microscope. It has two-layered shells: the outer shell is the envelope protein referred to as the hepatitis $B$ surface (HBs) protein, which is further divided into small, middle, and large HBs proteins (SHBs, MHBs and LHBs proteins, respectively), and the inner shell is a core protein referred to as the hepatitis $B$ core protein, in which the viral polymerase and the HBV genome are enclosed (Juergen Beck, 2007).

\section{HBV Genotype}

HBV genotypes can be localised into different geographical areas and are classified into 10 recognised genotypes (A-J) (Tatematsu et al., 2009; Yu et al., 2010). Genotype $A$ has been found to be dominant in Northern Europe and
North America while genotype $D$ is typically found in the Mediterranean region (Kreutz, 2002). In Asia, genotype A can be found at a high frequency in India, Indonesia and the Philippines (Weinberger et al., 2000). Genotypes B and C are found mainly in the Far East, such as in China, Japan and the South-East Asia region (Huy and Abe, 2004), genotype I is found in Vietnam, Laos, North western China and isolated valleys of northern India, while the $10^{\text {th }}$ genotype, $\mathrm{J}$, has been reported in a Japanese patient (Tatematsu et al., 2009). Therefore, in the Asia Pacific region, four genotypes $(\mathrm{B}, \mathrm{C}, \mathrm{I}$ and $\mathrm{J})$ largely dominate. These genotypes have discrete biological distributions with subtype adw found in genotypes A, B, C, F and G, while both adr and ayr occur in genotype $C$ alongside adw (Echevarría and Avellón, 2006).

\section{Pathogenesis of Hepatitis B infection}

The pathogenesis of hepatitis $B$ is due to the interaction of the virus and the host immune system in which the immune system attacks HBV and causes liver injury. Activated CD4 ${ }^{+}$ and $\mathrm{CD}^{+}$lymphocytes recognise various HBV-derived peptides located on the surface of the hepatocytes, leading to immunologic reaction, impaired immune reactions (e.g. cytokine release, antibody production) or a relatively tolerant immune status, resulting in chronic hepatitis. In particular, a restricted $\mathrm{T}$ cell-mediated lymphocytic response occurs against the HBV-infected hepatocytes (Yang et al., 2008). The first step in HBV infection involves a specific non-cell type primary attachment to the cellassociated heparin sulphate proteoglycans (Schulze et al., 2007). This first reversible attachment step is then followed by an irreversible binding of the virus to a specific, unknown hepatocyte-specific receptor (Urban et al., 2010). This step requires activation of the virus, resulting in exposure of the myristoylated $\mathrm{N}$-terminus of the L-protein. This is a vital determinant for infectivity within the HBV envelope proteins (Engelke et al., 2006). Potential HBV receptor candidates have been described in the past, but none has been confirmed in a functional assay (Glebe and Urban, 2007). However, recent studies indicated that cell polarisation, in addition to the differentiation status of the hepatocytes, plays an important role in the infection process (Schulze et al., 2012).

\section{Diagnosis of hepatitis $B$}

The detection of HBsAg remains the principal diagnostic test for hepatitis $B$, both in the routine virology laboratory and for blood donation screening; most infected individuals are also positive for antibodies to the nucleocapsid protein (anti$\mathrm{HBc}$ ). However, not all carriers of HBsAg have a substantial level of viraemia, this is because the number of infectious virus particles (viremia) is usually higher during the hepatitis $B$ e antigen infection phase and decreases during hepatitis $B$ e antibody (anti-HBe) phase, and subsequently disappears during anti-HBs. The clinical implication of this non viremic hepatitis B infection includes: contribution to progression of liver disease; may cause cryptogenic liver disease; and may contribute potential risk of HBV transmission through blood transfusion, organ transplant and haemodialysis. HBsAg may be produced from HBV DNA and get incorporated into the genomes of the hepatocytes without virus replication. However, a single change in the immunodominant region of HBsAg demonstrates the inconsistency whereby a polyclonal antibody may be more likely to fail to detect 
variant $\mathrm{HBsAg}$ with single amino acid substitutions than monoclonal antibody-based assays (Bruce and Murray, 1995), and multiple substitutions in HBsAg elucidate the real threat to surface antigen testing. The concern is that a failure to diagnose HBsAg will not only lead to diagnostic dilemmas, but also to transfusion-associated hepatitis B infection. The detection of hepatitis B viraemia is eased by an additional protein, the hepatitis $B$ e antigen ( $\mathrm{HBeAg})$, which is secreted by the infected hepatocytes. The presence of $\mathrm{HBeAg}$ in serum consistently indicates active virus replication in the liver. Normal $\mathrm{HBeAg}$ synthesis is usually altered by presence of mutation in the core and precore region of the HBV DNA (Tong et al., 2005). The most commonly reported mutation in precore involves $G$ to A base pair substititution at nucleotide 1896 region of the HBV genome (Funk et al., 2002) . The diagnosis of HBeAg negative in hepatitis $B$ chronic infection is by identification of high HBV DNA load. Precore and core-promoter mutations usually occur spontaneously or treatment-induced clearance of $\mathrm{HBeAg}$. Patients with $\mathrm{HBeAg}$ negative hepatitis $B$ chronic infection tend to be older than patients with wildtype infection (Hadziyannis and Vassilopoulos, 2001).

Therefore, screening before vaccination is recommended in areas of high prevalence of HBV infection; although no potential damage can occur when a carrier is vaccinated, it also confers no protection. Besides, these carries may be miscounseled about their HBV status and to believe that they have been protected while they are not and continue to be a source of infection to others. For those that are immune, vaccination would enhance their antibody levels. Hepatitis B surface antigen and antibodies are widely adopted as a screening test. Antibody to hepatitis $B$ core antigen (anti-HBc) when present indicates past infection but does not distinguish carriers from those who have recovered from an acute infection. A previous study showed that the proportion of patients with prior exposure to $\mathrm{HBV}$ was similar whether anti-HBc was measured alone or when $\mathrm{HBsAg}$ and anti-HBc were measured simultaneously (Liew et al., 2010).

\section{Treatment}

The currently approved hepatitis B infection therapies consist of interferon therapy and an antiviral composed of nucleotide and nucleoside analogues, which potentially provide long-term suppression of viral load; unfortunately, these are only associated with low rates of complete cure. The treatment of chronic hepatitis B is aimed at preventing transmission by eliminating infectivity and the spread of $\mathrm{HBV}$, stopping the progression of liver disease and preventing the development of HCC. Interferon is used in the treatment of Chronic hepatitis B (Parkin et al., 2001). Interferon has antiviral, immunomodulatory, and antiproliferative effects and is available in forms of pegylated (pegINF) and non-pegylated interferon. Pegylated interferon has a longer half-life than its non-pegylated counterpart, but they enhance T-cell helper activity, enhance the maturation of B lymphocytes, inhibit T-cell suppressors, and enhance human leukocyte antigen (HLA) type I expression.

\section{Hepatitis B Vaccine}

There are two types of HBV vaccine: plasma-derived vaccine, which has been in circulation since 1982, and recombinant yeast-derived vaccines which became available in 1986
(Francis et al., 1986). Hepatitis B vaccine containing yeastderived recombinant $\mathrm{HBsAg}$ protein provides an effective means of preventing HBV infection. A seroconversion rate up to $95 \%$ has been reported among vaccinates (Emini et al., 1986) and in a study in Thailand, where a yeast-derived vaccine was shown to have protective efficacy of $95 \%$ in infants of $\mathrm{HBeAg}$ positive mothers (Poovorawan et al., 1990). The HBsAg protein is a highly conformational and cysteine rich "a" determinant (Bertoletti and Gehring, 2006). Antibodies stimulated by active hepatitis B vaccination and anti-HBs antibody present in HBlg are mainly directed to this region of the HBsAg protein ( $X u$ et al., 2010). Conversely, other relevant antigenic epitopes outside the "a" determinant and situated on the surface of the virus have also been described (Chen et al., 1996) Some of these epitopes are situated downstream of the "a" determinant and may be potential neutralisation domains (Irving et al., 2001). Mutations within the "a" determinant can alter the antigenicity of the HBsAg protein which could lead to a failure of anti-HBs antibodies to neutralise HBV (Carman et al., 1997; Hsu et al., 1999). It has been estimated that vaccine-escape mutants will become the dominant HBV quasi species globally (Wilson et al., 1999). Serologic tests carried out after immunisations are intended to evaluate immunity, identifying non-responsive or weak-response individuals. A response is considered absent whenever antiHBs titres are less than $10 \mathrm{IU} / \mathrm{L}$ and ineffective when titres are less than $100 \mathrm{IU} / \mathrm{L}$ at least one month, post hepatitis $B$ vaccine booster dose.

\section{Hepatitis B surface antigen}

Hepatitis B surface antigen particles consist primarily of a glycoprotein with 226 amino acids that carry the B-cell epitopes essential for the induction of protective antibodies in humans and which confer immunity against hepatitis $B$ infection. It has been clearly shown that the region between amino acids 124 and 147 of the S protein represents the "a" determinants (Zheng et al., 2004) common to all HBV variants and is exposed on the surface of the HBV particle. Anti-"a" antibodies protect adults against the majority of infections irrespective of the subtype of the wild-type virus (Zheng et al., 2004).

\section{Hepatitis B Surface Mutation}

Mutations in the HBsAg, also called surface (S) mutations, have several clinical effects, including: (i) reduced sensitivity to available diagnostic tests, (ii) a lack of immunity following vaccination with non-mutant $\mathrm{HBV}$ variants (vaccine escaped mutant) and (iii) a failure of passive immunisation with HBV IgG (El Chaar, 2010). The failure of a diagnostic assay may be a major threat to recipients of blood transfusions or organ transplants (Levicnik-Stezinar, 2004; Thakur et al., 2005). Hepatitis B surface mutants are stable and can be spread through either vertical or horizontal transmission (Hunt et al., 2000). In Asian infants, vertical transmission is the most common ( $2 \%$ to $3 \%$ of vaccine recipients) (Hunt et al., 2000). This may be due to vaccination and administration of hepatitis B immunoglobulin ( $\mathrm{HBlg}$ ) at birth, exerting evolutional pressures to select mutants (Wu et al., 2010). However, research has shown that vaccinated children are more likely to harbour mutations than unvaccinated children, possibly due to the fact that neutralisation-resistant $\mathrm{HBV}$ variants may be selected 
as a result of pressure from the vaccine-induced immune response (Carman et al., 1990). On the other hand, a delay of three months before administration of the vaccine to the child will allow replication of the hepatitis $B$ virus to proceed in the liver, with the mutant emerging possibly even before vaccination. The antibody response to vaccination would then have imposed the selection pressure necessary to allow the "escape" mutant to replicate in an unrestricted manner. However, there is contradictory evidence as to whether escape mutants arise de novo in infected infants (in which instance vaccination would have played a direct role in inducing the emergence of the mutants) or whether the mutants, having pre-existed maternally, subsequently undergo selective replication in the infant under immune pressure, hence the need for further study to ascertain the claims.

The common immunodominant B-cell epitope cluster shared by different subtypes of HBV situated within the "a" determinant region (124-147 amino acid), is regarded as the neutralising epitope of the $S$ protein. Single or multiple mutations occurring within the Major Hydrophilic Region (MHR) could lead to a conformational change of this epitope which can affect the antigenicity (Ma and Wang, 2012). Several notable mutations: T/I126S, Q129H, G130N, S143L, D144A, G145A, and G145R (Figure 2), are involved in diagnostic failure, and escape from being neutralised by antibodies induced by available vaccines as well as resulting in a failure of HBIg therapy (Jolivet-Reynaud et al., 2001). On the other hand, mutations outside the "a" determinant region are located primarily at positions 120 and 123 . The Pro at position 120 can mutate to Gly/Thr/Ser/Asn/GIn (Jolivet-Reynaud et al., 2001), and mutation at position 123 gives rise to $T 123 \mathrm{~N}$, which is responsible for both diagnostic and HBIg therapeutic failure (Ly et al., 2006).

In Cambodia, the majority of the mutations occur outside the "a" determinant region resulting in amino acid substitutions (Srey et al., 2006). In Vietnam, three M133L mutations have been found in the first loop of the "a" determinant, no mutation was identified within the second loop, while T126M was found in one sample (Thuy et al., 2005). In Singapore, HBsAg mutation was found in neonates of $\mathrm{HBsAg}$ positive mothers; 16 (39\%) of 41 neonates showed breakthrough infection despite HBIg and a full course of a plasma-derived vaccine being given (Chong-Jin et al., 1999). However, in Thailand, $22.4 \%$ of vaccinated and unvaccinated children were found to have varying mutations in the "a" determinant region of HBV (Poovorawan et al., 2012). In Malaysia, mutations were observed in $11 \%$ of patients receiving antiviral therapy, of which, $8 \%$ carried mutants previously described as vaccineassociated escape mutants and seven strains (9\%) carried other types of mutants (Meldal et al., 2011). Although the introduction of hepatitis B vaccination program in Asia Pacific countries has been effective, the emergence of anti-HBc in vaccinated individuals suggested the possibility of contact with hepatitis B infection with mutant strains subsequent to vaccination (Huang et al., 2009; Xu et al., 2010).

\section{Mechanisms of HBsAg mutation}

Numerous mechanisms can lead to mutations in the HBV genome. However, the viral polymerase lacks a proofreading function and, together with the cellular RNA polymerase II, are the main driving forces for the emergence

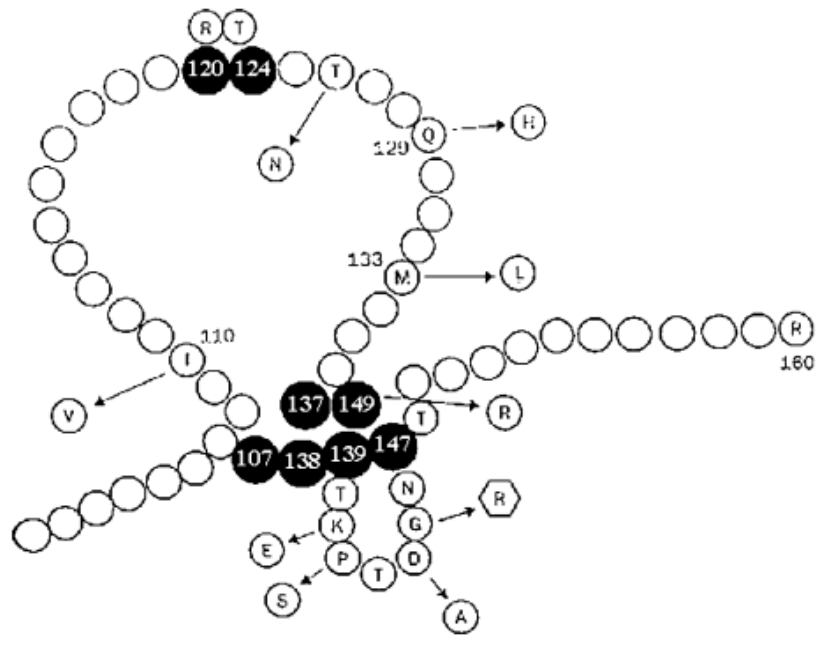

Figure 2. Molecular structure of the major hydrophilic region of the "a" determinant of HBsAg between amino acids 100-160. Letters in circles are viral variants associated with vaccination; most are clustered in the region around amino acids 137-147. The most common and most stable mutation is G145R. Shaded areas indicate disulphide bonds (source: Zuckerman and Zuckerman, 2003).

of point-mutations in the HBV genome (Steinhauer and Holland, 1986). Viral mutations are controlled by functional limitations (Mizokami et al., 1997) and, therefore, variation is not random within the HBV genome (Yang and Summers, 1995). Likewise, selective pressure and interaction between hosts and viruses, imposed exogenously by vaccination and antiviral treatments with hepatitis B immunoglobulin ( $\mathrm{HBlg})$, nucleoside analogues or interferon alpha, as well as endogenously by the host immune system, can also affect the mutation selection balance of the HBV genome and apply selective pressures on HBV in infected individuals, leading to the generation and build-up of mutations in the $S$ gene. Most of these mutations occur in the MHR of the $S$ gene, leading to alterations in the structure of the hepatitis $B$ surface antigen, which can disrupt the binding of polyclonal antibodies (Kreutz, 2002). These alterations consist of mutations to the cysteine residue involved in the formation of the disulphide bridges that are responsible for the double-loop structure of the MHR (Seddigh-Tonekaboni et al., 2001; Wakil et al., 2002) and their modifications to protein acidity, electric charge and hydrophobicity (Thakur et al., 2003). Some mutations involve amino acid insertions into the "a" determinant (Lazarevic et al., 2010; Weinberger et al., 2000) or through the creation of stop codons at an inappropriate position, leading to premature termination of the amino acid sequence (Thuy et al., 2005), while other mutations eliminate the glycosylation site at position 146 of the protein (Roznovsky et al., 2000) or create potential new glycosylation sites in the first loop of the MHR (Koyanagi et al., 2000). However, not all mutations in the MHR lead to escape mutants (Avellón and Echevarria, 2006; Kazim et al., 2006). The administration of antiviral drugs, like lamivudine, which inhibits viral polymerase activity, can lead to 
mutations in the polymerase gene. Consequently, because of the overlap of the polymerase and $S$ genes, a change in the polymerase has the potential to cause mutations in the $\mathrm{S}$ gene. Thus, lamivudine therapy is associated with the generation of escape mutants (Kazim et al., 2006); these are HBV mutants carrying amino acid sequence variations within the "a" determinant and are not neutralised by antibodies induced by the recombinant vaccine, therefore causing infection in vaccinated individuals.

\section{HBsAg mutation and blood donation}

Transfusion-associated hepatitis B signifies a global public health problem. Routine screening of HBsAg among blood donors implemented in the early 1970s has significantly enhanced transfusion safety and has steadily reduced the incidence of transfusion-transmitted hepatitis B over the last four decades (Niederhauser et al., 2008). On the other hand, it was demonstrated that HBV transmission by blood components that are negative for HBsAg can still occur (Kuhns et al., 2004) and HBV transmission remained the most frequent transfusion-transmitted viral infection (Liu et al., 2006). Subject to how blood donors were selected and screened, it has been shown that intermediate to high levels of circulating HBV in Asia Pacific is increasing the likelihood of contamination of blood transfusion (Xu et al., 2010). Although prevention and control is the most effective approach to assist in decreasing the spread of hepatitis $B$ infection, an increase in the number of infected individuals similarly creates a circumstance in which evolutionary progressions can lead to the emergence of new HBV isolates that are capable of evading detection, thereby entering the blood circulation (Liu et al., 2010). An assessment of screening techniques might provide insights into strategies that could possibly make blood transfusion safe. To reduce the levels of post-transfusion hepatitis in the Asia Pacific region, the feasibility and effectiveness of using multiple immunoassays or nucleic acid-based amplification assays such as PCR, DNA dot-blot hybridisation assays and Nucleic acid amplification test (NAT) should be evaluated for the effective prevention of post-transfusion hepatitis, especially those cases that are due to HBsAg mutants. NAT complements serological screening for blood donors and reduces the rate of transfusion-associated infection because it has the ability to detect the presence of infection by directly testing viral nucleic acid rather than antibodies. It is capable of detecting small amounts of DNA or RNA; this is beneficial during the window period and for occult hepatitis. However, in most Asia Pacific countries, this method is not cost-effective (Liu et al., 2006). Therefore, screening for $\mathrm{HBsAg}$ and total anti-HBc is important in the prevention of post-transfusion hepatitis. In Malaysia, it was found that the presence of $\mathrm{HBsAg}$ and anti-HBc in blood donors from the Kuala Lumpur hospital was $5.5 \%$, and $50.1 \%$, respectively (Ton et al., 1979). However, the HBV infection rate has been significantly reduced since the introduction of a nationwide vaccination program in 1989 ( $\mathrm{Ng}$ et al., 2005). In blood donors in Indonesia, analysis of antigenic marker and de novo prediction of tertiary conformation of the three $\mathrm{HBsAg}$ variants $(\mathrm{T} 123 \mathrm{~A}, \mathrm{M} 133 \mathrm{~L}$, and $\mathrm{T} 143 \mathrm{M})$ revealed that $\mathrm{T} 143 \mathrm{M}$ will alter antigenicity in comparison with the other two mutation patterns (le Susan I, 2010). The safety of blood transfusion may be compromised as a result of donors that are infected with HBsAg mutants, as well as those with circulating undetectable levels of viral protein, which can escape detection by common screening tests as a result of alterations in the "a" determinant region of the S gene (Qiu et al., 2008). However, more accurate and cost-effective tests are increasingly required to prevent the risk of contracting an infection by receiving a contaminated blood unit (Kosan et al., 2010).

\section{HBsAg mutation and hepatocellular carcinoma}

Hepatitis B surface antigen mutants are asymptomatic and would only be detected by routine screening. No available guidelines are provided for categorising those who should be screened for surface antigen mutants. Nevertheless, such screening should be considered in the following situations: blood donors, subjects with unexplained liver diseases and subjects who are HBsAg negative but anti-HBc and/or antiHBs positive. This is further elucidated by Candotti et al., who showed that surface mutants are commonly seen in habitual donors, with almost $100 \%$ carrying anti-HBc, and $50 \%$ anti$\mathrm{HBs}$, signifying the occurrence of surface mutations mostly in individuals that recovered from infection but were unable to develop effective immune control (Candotti et al., 2008).

Hepatocellular carcinoma (HCC), accounts for $85-90 \%$ of liver cancers worldwide (McMahon et al., 2009). Between 500,000 and 1 million new HCC cases are diagnosed annually, with an age-adjusted annual rate of 14.9 per 100,000 in men, and 5.5 per 100,000 in women (Gomaa et al., 2008; Jolivet-Reynaud et al., 2001). In the highly endemic Asia-Pacific region, HBV infection accounts for $17 \%$ of HCC cases in Japan (Lemon et al., 2000), but is associated with up to $80-90 \%$ of HCC cases in Singapore and Vietnam (Pokorski and Ohlmer, 2001). HBsAg mutants have been shown to aid in the development of hepatocellular carcinoma through the capability of independent replication, infectivity in chimpanzees and participation in acute human hepatitis (Hunt et al., 2000; Ogata et al., 1997). The occurrence of hepatitis B surface mutants in HCC patients, using variations within the "a" determinant region of $\mathrm{HBsAg}$ that are comparable to those described in vaccine escape, were reported in Singapore (Oon et al., 1995). Similarly, 20 cases of HBsAg mutants detected in Singapore among patients with $\mathrm{HCC}$ were found to have mutations at positions G145A and M133T (Chemin et al., 2001). The highest rates are in Southeast Asia and sub-Saharan Africa, with the HCC incidence being more than 50/100 (Chemin et al., 2001). The introduction of hepatitis $B$ vaccination worldwide has demonstrated effectiveness in the prevention of HCC, as supported by several studies in Asia Pacific ( $\mathrm{Li}$ et al., 2004). In Taiwan, it has been reported that the rate of HCC in children aged 6 to 14 years has significantly dropped from 0.70 per 100,000 children in 1981 to 1986 to 0.57 from 1986 to 1990 , and to 0.36 from 1990 to $1994(P<0.01)$ in the vaccinated cohort (Li et al., 2004).

\section{Conclusion}

In conclusion, this review sheds light on fundamental aspects of HBV surface antigen mutations that are essential for the diagnosis of HBV infection, which can lead to the development of severe diseases such as HCC, and pose a risk of transmission through blood donation. However, good knowledge of detailed structural and physiochemical changes as a result of mutations within the $S$ gene is required to define which mutants regulate $S$ gene antigenicity, 
as well as the need for guidelines on the diagnosis and management of HBsAg mutant infection. A country-based research on the type of prevailing mutants will no doubt help in elucidating the perspective of HBsAg mutants in South East Asia to make diagnostics and blood transfusion safe.

\section{Authors' contributions}

This information was compiled as part of the literature review of my Master of Science thesis entitled "Molecular detection of hepatitis B surface antigen, mutant and evaluation of post hepatitis B vaccination" which was substantially revised by ZS, YAM, NMT and NSH. All authors read and approved the final manuscript.

\section{Conflict of interest}

We express no competing interests.

\section{References}

Abbas, Z., Jafri, W., Shah, S., Khokhar, N., and Zuberi, S. (2004). PGS Consensus statement on management of Hepatitis B virus infection-2003. Journal-Pakistan Medical Association 54, 150-158.

Avellón, A., and Echevarria, J.M. (2006). Frequency of hepatitis B virus 'a'determinant variants in unselected Spanish chronic carriers. Journal of Medical Virology 78 , 24-36.

Bertoletti, A., and Gehring, A.J. (2006). The immune response during hepatitis $B$ virus infection. Journal of General Virology 87, 1439-1449.

Blumberg B. S., G.B.J., Hungerford D. A., London W. T., Sutnick, A. I. (1967). A serum antigen (Australia antigen) in Down's syndrome, leukemia, and hepatitis. Annals of internal medicine 66, 924-931.

Botha, J., Dusheiko, G., Ritchie, M., Mouton, H., and Kew, M. (1984). Hepatitis B virus carrier state in black children in Ovamboland: role of perinatal and horizontal infection. The Lancet 323, 1210-1212.

Bruce, S.A., and Murray, K. (1995). Mutations of some critical amino acid residues in the hepatitis $B$ virus surface antigen. Journal of Medical Virology 46, 157-161.

Candotti, D., Grabarczyk, P., Ghiazza, P., Roig, R., Casamitjana, N., ludicone, P., Schmidt, M., Bird, A., Crookes, R., and Brojer, E. (2008). Characterization of occult hepatitis $B$ virus from blood donors carrying genotype A2 or genotype D strains. Journal of Hepatology 49, 537-547.

Carman, W.F., Karayiannis, P., Waters, J., Thomas, H., Zanetti, A., Manzillo, G., and Zuckerman, A.t. (1990). Vaccine-induced escape mutant of hepatitis $B$ virus. The Lancet 336, 325-329.

Carman, W.F., Van Deursen, F.J., Mimms, L.T., Hardie, D., Coppola, R., Decker, R., and Sanders, R. (1997). The prevalence of surface antigen variants of hepatitis $B$ virus in Papua New Guinea, South Africa, and Sardinia. Hepatology 26, 1658-1666.

Chemin, I., Jeantet, D., Kay, A., and Trepo, C. (2001). Role of silent hepatitis $B$ virus in chronic hepatitis $B$ surface antigen (-) liver disease. Antiviral Research 52, 117-123.

Chen, C.-Y., Hsu, H.-Y., Liu, C.-C., Chang, M.-H., and Ni, Y.-H. (2010). Stable seroepidemiology of hepatitis $B$ after universal immunization in Taiwan: a 3-year study of national surveillance of primary school students. Vaccine $28,5605-5608$.
Chen Chien-Jen, W.L.-Y., Yu Ming-Whei (2000). Epidemiology of hepatitis $B$ virus infection in the Asia-Pacific region. Journal of Gastroenterology and Hepatology 15, E3-E6.

Chen, Y., Delbrook, K., Dealwis, C., Mimms, L., Mushahwar, I.K., and Mandecki, W. (1996). Discontinuous epitopes of hepatitis B surface antigen derived from a filamentous phage peptide library. Proceedings of the National Academy of Sciences 93, 1997-2001.

Chong-Jin, O., Ning, C.W., Shiuan, K., and Keow, L.G. (1999). Identification of hepatitis B surface antigen variants with alterations outside the "a" determinant in immunized Singapore infants. Journal of Infectious Diseases 179, 259-263.

Clements, C.J., Baoping, Y., Crouch, A., Hipgrave, D., Mansoor, O., Nelson, C.B., Treleaven, S., van Konkelenberg, R., and Wiersma, S. (2006). Progress in the control of hepatitis B infection in the Western Pacific Region. Vaccine 24, 1975-1982.

Dwivedi, M., Misra, S.P., Misra, V., Pandey, A., Pant, S., Singh, R., and Verma, M. (2011). Seroprevalence of hepatitis $B$ infection during pregnancy and risk of perinatal transmission. Indian Journal of Gastroenterology 30, 6671.

Echevarría, J.M., and Avellón, A. (2006). Hepatitis B virus genetic diversity. Journal of Medical Virology 78, S36-S42.

El Chaar, M.C., Daniel Crowther, R. Anthony Allain, Jean Pierre (2010). Impact of hepatitis B virus surface protein mutations on the diagnosis of occult hepatitis $B$ virus infection. Hepatology 52, 1600-1610.

Emini, E.A., Ellis, R.W., Miller, W.J., McAleer, W.J., Scolnick, E.M., and Gerety, R.J. (1986). Production and immunological analysis of recombinant hepatitis $B$ vaccine. Journal of Infection 13, 3-9.

Engelke, M., Mills, K., Seitz, S., Simon, P., Gripon, P., Schnölzer, M., and Urban, S. (2006). Characterization of a hepatitis $B$ and hepatitis delta virus receptor binding site. Hepatology 43, 750-760.

Francis, D.P., Feorino, P.M., McDougal, S., Warfield, D., Getchell, J., Cabradilla, C., Tong, M., Miller, W.J., Schultz, L.D., and Bailey, F.J. (1986). The safety of the hepatitis $B$ vaccine. JAMA: The Journal of the American Medical Association 256, 869-872.

Funk, M.L., Rosenberg, D.M., and Lok, A.S.F. (2002). World-wide epidemiology of $\mathrm{HBeAg}$-negative chronic hepatitis $B$ and associated precore and core promoter variants. Journal of Viral Hepatitis 9, 52-61.

Glebe, D., and Urban, S. (2007). Viral and cellular determinants involved in hepadnaviral entry. World Journal of Gastroenterology 13, 22.

Gomaa, A.I., Khan, S.A., Toledano, M.B., Waked, I., and Taylor-Robinson, S.D. (2008). Hepatocellular carcinoma: epidemiology, risk factors and pathogenesis. World journal of gastroenterology: WJG 14, 4300.

Hadziyannis, S.J., and Vassilopoulos, D. (2001). Hepatitis $\mathrm{B}$ e antigen-negative chronic hepatitis B. Hepatology 34, 617-624.

Hong, W.W., Ang, L.W., Cutter, J.L., James, L., Chew, S.K., and Goh, K.T. (2010). Changing seroprevalence of hepatitis B virus markers of adults in Singapore. Ann Acad Med Singapore 39, 591-598.

Hsu, H.Y., Chang, M.H., Liaw, S.H., Ni, Y.H., and Chen, H.L. (1999). Changes of hepatitis $B$ surface antigen variants in 
carrier children before and after universal vaccination in Taiwan. Hepatology 30, 1312-1317.

Huang, C.-F., Dai, C.-Y., Chuang, W.-L., Ho, C.-K., Wu, T.C., Hou, N.-J., Wang, C.-L., Hsieh, M.-Y., Huang, J.-F., and Lin, Z.-Y. (2009). HBV infection in indigenous children, 20 years after immunization in Taiwan: a community-based study. Preventive medicine 48, 397-400.

Hunt, C.M., McGill, J.M., Allen, M.I., and Condreay, L.D. (2000). Clinical relevance of hepatitis B viral mutations. Hepatology 31, 1037-1044.

Huy, T.T., and Abe, K. (2004). Molecular epidemiology of hepatitis $B$ and $C$ virus infections in Asia. Pediatrics international 46, 223-230.

le Susan I, T.M.D., Roni Martono, and Muljono David H (2010). Prediction of conformational changes by single mutation in the hepatitis B virus surface antigen ( $\mathrm{HBsAg}$ ) identified in HBsAg-negative blood donors. Virology Journal 7, 326.

Irving, M.B., Pan, O., and Scott, J.K. (2001). Randompeptide libraries and antigen-fragment libraries for epitope mapping and the development of vaccines and diagnostics. Current opinion in chemical biology 5, 314324.

Jolivet-Reynaud, C., Lesenechal, M., O'Donnell, B., Becquart, L., Foussadier, A., Forge, F., Battail-Poirot, N., Lacoux, X., Carman, W., and Jolivet, M. (2001). Localization of hepatitis $B$ surface antigen epitopes present on variants and specifically recognised by antihepatitis B surface antigen monoclonal antibodies. Journal of Medical Virology 65, 241-249.

Juergen Beck, M.N. (2007). Hepatitis B virus replication. World Journal of Gastroenterology 7, 48-64.

Jutavijittum, P., Yousukh, A., Samountry, B., Samountry, K., Ounavong, A., Thammavong, T., Keokhamphue, J., and Toriyama, K. (2007). Seroprevalence of hepatitis B and C virus infections among Lao blood donors.

Kazim, S.N., Sarin, S.K., Sharma, B.C., Khan, L.A., and Hasnain, S.E. (2006). Characterization of naturally occurring and Lamivudine-induced surface gene mutants of hepatitis $B$ virus in patients with chronic hepatitis $B$ in India. Intervirology 49, 152-160.

Kosan, E., Kocazeybek, B., Altunay, H., Aymelek, M., Alan, E., Saribas, S., Aslan, M., Yenen, O.S., Yuksel, P., and Birinci, I. (2010). Can the nucleic acid amplification test (NAT) be an alternative to the serologic tests? A prospective study, the results of 18,200 blood donors from the Turkish Red Crescent. Transfusion and Apheresis Science 43, 269-272.

Koyanagi, T., Nakamuta, M., Sakai, H., Sugimoto, R., Enjoji, M., Koto, K., Iwamoto, H., Kumazawa, T., Mukaide, M., and Nawata, H. (2000). Analysis of HBs antigen negative variant of hepatitis B virus: unique substitutions, Glu129 to Asp and Gly145 to Ala in the surface antigen gene. Medical science monitor: international medical journal of experimental and clinical research 6, 1165.

Kreutz, C. (2002). Molecular, immunological and clinical properties of mutated hepatitis B viruses. Journal of cellular and molecular medicine 6, 113-143.

Kuhns, M.C., Kleinman, S.H., McNamara, A.L., Rawal, B., Glynn, S., and Busch, M.P. (2004). Lack of correlation between HBsAg and HBV DNA levels in blood donors who test positive for HBsAg and anti-HBc: implications for future HBV screening policy. Transfusion 44, 1332-1339.
Lazarevic, I., Cupic, M., Delic, D., Svirtlih, N.S., Simonovic, J., and Jovanovic, T. (2010). Prevalence of hepatitis B virus MHR mutations and their correlation with genotypes and antiviral therapy in chronically infected patients in Serbia. Journal of Medical Virology 82, 1160-1167.

Lee, J.M., and Ahn, S.H. (2011). Quantification of HBsAg: basic virology for clinical practice. World journal of gastroenterology: WJG 17, 283.

Lemon, S.M., Layden, T.J., Seeff, L., Suzuki, H., Nishioka, K., Mishiro, S., and Johnson, L. (2000). The 20th United States-Japan joint hepatitis panel meeting. Hepatology 31, 800-806.

Levicnik-Stezinar, S. (2004). Hepatitis B surface antigen escape mutant in a first time blood donor potentially missed by a routine screening assay. Clinical laboratory $50,49$.

Li, R., Yang, J., Gong, J., Li, Y., Huang, Z., Fang, K., Xu, Z., Liu, C., Zhao, K., and Zhuang, H. (2004). Efficacy of hepatitis $B$ vaccination on hepatitis $B$ prevention and on hepatocellular carcinoma]. Zhonghua liu xing bing xue za zhi= Zhonghua liuxingbingxue zazhi 25, 385.

Liew, F., Ang, L.W., Cutter, J., James, L., and Goh, K.T. (2010). Evaluation on the effectiveness of the national childhood immunisation programme in Singapore, 19822007. Annals Academy of Medicine Singapore 39, 532.

Liu, C.-J., Chen, D.-S., and Chen, P.-J. (2006). Epidemiology of HBV infection in Asian blood donors: emphasis on occult HBV infection and the role of NAT. Journal of clinical virology 36, S33-S44.

Liu, Y., Li, P., Li, C., Zhou, J., Wu, C., and Zhou, Y.-H. (2010). Detection of hepatitis B virus DNA among accepted blood donors in Nanjing, China. Virol J 7, 193.

Lu, F., Li, T., Liu, S., and Zhuang, H. (2010). Epidemiology and prevention of hepatitis $B$ virus infection in China. Journal of Viral Hepatitis 17, 4-9.

Ly, T.D., Servant-Delmas, A., Bagot, S., Gonzalo, S., Férey, M.-P., Ebel, A., Dussaix, E., Laperche, S., and Roque-Afonso, A.-M. (2006). Sensitivities of four new commercial hepatitis $B$ virus surface antigen ( $\mathrm{HBsAg}$ ) assays in detection of HBsAg mutant forms. Journal of Clinical Microbiology 44, 2321-2326.

Ma, Q., and Wang, Y. (2012). Comprehensive analysis of the prevalence of hepatitis $B$ virus escape mutations in the major hydrophilic region of surface antigen. J Med Virol 84, 198-206.

McMahon, B.J. (2005). Epidemiology and natural history of hepatitis B. Paper presented at: SEMINARS IN LIVER DISEASE (Published in 2005 by Thieme Medical Publishers, Inc., 333 Seventh Avenue, New York, NY 10001, USA.).

McMahon, B.J., Dentinger, C.M., Bruden, D., Zanis, C., Peters, H., Hurlburt, D., Bulkow, L., Fiore, A.E., Bell, B.P., and Hennessy, T.W. (2009). Antibody levels and protection after hepatitis B vaccine: results of a 22-year follow-up study and response to a booster dose. The Journal of infectious diseases 200, 1390-1396.

Meldal, B.H.M., Bon, A.H., Prati, D., Ayob, Y., and Allain, J.P. (2011). Diversity of Hepatitis B virus infecting Malaysian candidate blood donors is driven by viral and host factors. Journal of Viral Hepatitis 18, 91-101.

Mizokami, M., Orito, E., Ohba, K.-i., Ikeo, K., Lau, J.Y., and Gojobori, T. (1997). Constrained evolution with respect to gene overlap of hepatitis $B$ virus. Journal of molecular 
evolution 44, S83-S90.

Ng, K.P., Saw, T.L., Baki, A., Rozainah, K., Pang, K.W., and Ramanathan, M. (2005). Impact of the Expanded Program of Immunization against hepatitis B infection in school children in Malaysia. Med Microbiol Immunol 194, 163-168.

Niederhauser, C., Graziani, M., Stolz, M., Tinguely, C., and Schneider, P. (2008). Blood donor screening: how to decrease the risk of transfusion-transmitted hepatitis $B$ virus? Swiss medical weekly 138, 134-141.

Ogata, N., Zanetti, A.R., Yu, M., Miller, R.H., and Purcell, R.H. (1997). Infectivity and pathogenicity in chimpanzees of a surface gene mutant of hepatitis $B$ virus that emerged in a vaccinated infant. Journal of Infectious Diseases 175 , 511-523.

Olinger, C.M., Jutavijittum, P., Hübschen, J.M., Yousukh, A., Samountry, B., Thammavong, T., Toriyama, K., and Muller, C.P. (2008). Possible new hepatitis B virus genotype, southeast Asia. Emerging infectious diseases 14, 1777.

Oon, C.-J., Lim, G.-K., Ye, Z., Goh, K.-T., Tan, K.-L., Yo, S.L., Hopes, E., Harrison, T.J., and Zuckerman, A.J. (1995). Molecular epidemiology of hepatitis $B$ virus vaccine variants in Singapore. Vaccine 13, 699-702.

Parkin, D.M., Bray, F., Ferlay, J., and Pisani, P. (2001). Estimating the world cancer burden: Globocan 2000. International Journal of Cancer 94, 153-156.

Pokorski, R.J., and Ohlmer, U. (2001). Long-term morbidity and mortality in Chinese insurance applicants infected with the hepatitis B virus. Journal of Insurance MedicineNew York- 33, 143-164.

Poovorawan, Y., Chongsrisawat, V., Theamboonlers, A., Leroux-Roels, G., Crasta, P.D., and Hardt, K. (2012). Persistence and immune memory to hepatitis $B$ vaccine 20 years after primary vaccination of Thai infants, born to $\mathrm{HBsAg}$ and $\mathrm{HBeAg}$ positive mothers. Human vaccines \& immunotherapeutics 8, 896-904.

Poovorawan, Y., Sanpavat, S., Pongpunlet, W., Chumdermpadetsuk, S., Sentrakul, P., Chitinand, S., Sakulramrung, R., and Tannirundorn, Y. (1990). Comparison of a recombinant DNA hepatitis $B$ vaccine alone or in combination with hepatitis $B$ immune globulin for the prevention of perinatal acquisition of hepatitis $B$ carriage. Vaccine 8, S56-S59.

Qiu, S., Zhang, J., Tian, Y., Yang, Y., Huang, H., Yang, D., Lu, M., and Xu, Y. (2008). Reduced antigenicity of naturally occurring hepatitis B surface antigen variants with substitutions at the amino acid residue 126. Intervirology 51, 400-406.

Roznovsky, L., Harrison, T.J., Fang, Z.L., Ling, R., Lochman, I., Orsagova, I., and Pliskova, L. (2000). Unusual hepatitis $B$ surface antigen variation in a child immunised against hepatitis B. Journal of Medical Virology 61, 11-14.

Scaglioni, P.P., Melegari, Margherita Wands, Jack R. (1996). Recent advances in the molecular biology of hepatitis $B$ virus. Baillière's Clinical Gastroenterology 10, 207-225.

Schulze, A., Gripon, P., and Urban, S. (2007). Hepatitis $B$ virus infection initiates with a large surface proteindependent binding to heparan sulfate proteoglycans. Hepatology 46, 1759-1768.

Schulze, A., Mills, K., Weiss, T.S., and Urban, S. (2012). Hepatocyte polarization is essential for the productive entry of the hepatitis B virus. Hepatology 55, 373-383.
Seddigh-Tonekaboni, S., Lim, W., Young, B., Hou, J.L., Waters, J., Luo, K.X., Thomas, H., and Karayiannis, P. (2001). Hepatitis B surface antigen variants in vaccinees, blood donors and an interferon-treated patient. Journal of Viral Hepatitis 8, 154-158.

Shao, Z.J., Zhang, L., Xu, J.Q., Xu, D.Z., Men, K., Zhang, J.X., Cui, H.C., and Yan, Y.P. (2011). Mother-to-infant transmission of hepatitis $B$ virus: A Chinese experience. Journal of Medical Virology 83, 791-795.

Soeung, S.C., Rani, M., Huong, V., Sarath, S., Kimly, C., and Kohei, T. (2009). Results from nationwide hepatitis $B$ serosurvey in Cambodia using simple and rapid laboratory test: implications for National Immunization Program. The American Journal of Tropical Medicine and Hygiene 81, 252-257.

Srey, C.T., ljaz, S., Tedder, R.S., and Monchy, D. (2006). Characterization of hepatitis $B$ surface antigen strains circulating in the Kingdom of Cambodia. J Viral Hepat 13, 62-66.

Steinhauer, D.A., and Holland, J.J. (1986). Direct method for quantitation of extreme polymerase error frequencies at selected single base sites in viral RNA. Journal of Virology 57, 219-228.

Tatematsu, K., Tanaka, Y., Kurbanov, F., Sugauchi, F., Mano, S., Maeshiro, T., Nakayoshi, T., Wakuta, M., Miyakawa, Y., and Mizokami, M. (2009). A genetic variant of hepatitis $B$ virus divergent from known human and ape genotypes isolated from a Japanese patient and provisionally assigned to new genotype J. Journal of Virology 83, 10538-10547.

Thakur, V., Kazim, S.N., Guptan, R.C., Hasnain, S.E., Bartholomeusz, A., Malhotra, V., and Sarin, S.K. (2005). Transmission of G145R mutant of HBV to an unrelated contact. Journal of Medical Virology 76, 40-46.

Thakur, V., Kazim, S.N., Guptan, R.C., Malhotra, V., and Sarin, S.K. (2003). Molecular epidemiology and transmission of hepatitis $B$ virus in close family contacts of HBV-related chronic liver disease patients. Journal of Medical Virology 70, 520-528.

Thuy, T., Thi, L., Ryo, H., Van Phung, L., Furitsu, K., and Nomura, T. (2005). Distribution of genotype/subtype and mutational spectra of the surface gene of hepatitis $B$ virus circulating in Hanoi, Vietnam. Journal of Medical Virology 76, 161-169.

Ton, S., Lopez, C., and Hasnah, H. (1979). Prevalence of anti-HBc in Malaysian male blood donors and its correlation with DNA polymerase activity. The Southeast Asian journal of tropical medicine and public health 10, 1.

Tong, S., Kim, K.H., Chante, C., Wands, J., and Li, J. (2005). Hepatitis B Virus e Antigen Variants. Int J Med Sci 2, 2-7.

Urban, S., Schulze, A., Dandri, M., and Petersen, J. (2010). The replication cycle of hepatitis $B$ virus. Journal of Hepatology 52, 282-284.

Wakil, S.M., Kazim, S.N., Khan, L.A., Raisuddin, S., Parvez, M.K., Guptan, R.C., Thakur, V., Hasnain, S.E., and Sarin, S.K. (2002). Prevalence and profile of mutations associated with lamivudine therapy in Indian patients with chronic hepatitis $B$ in the surface and polymerase genes of hepatitis B virus. Journal of Medical Virology 68, 311318.

Weinberger, K.M., Bauer, T., Böhm, S., and Jilg, W. (2000). High genetic variability of the group-specific a-determinant of hepatitis $B$ virus surface antigen ( $\mathrm{HBsAg}$ ) and the 
corresponding fragment of the viral polymerase in chronic virus carriers lacking detectable HBsAg in serum. Journal of General Virology 81, 1165-1174.

Wilson, J.N., Nokes, D.J., and Carman, W.F. (1999). The predicted pattern of emergence of vaccine-resistant hepatitis B: a cause for concern? Vaccine 17, 973-978.

Wu, C., Zhang, X., Tian, Y., Song, J., Yang, D., Roggendorf, M., Lu, M., and Chen, X. (2010). Biological significance of amino acid substitutions in hepatitis $B$ surface antigen (HBsAg) for glycosylation, secretion, antigenicity and immunogenicity of $\mathrm{HBsAg}$ and hepatitis $\mathrm{B}$ virus replication. Journal of General Virology 91, 483-492.

Xu, L., Wei, Y., Chen, T., Lu, J., Zhu, C.-L., Ni, Z., Huang, F., Du, J., Sun, Z., and Qu, C. (2010). Occult HBV infection in anti-HBs-positive young adults after neonatal HB vaccination. Vaccine 28, 5986-5992.

Yang, H.-I., Yeh, S.-H., Chen, P.-J., Iloeje, U.H., Jen, C.L., Su, J., Wang, L.-Y., Lu, S.-N., You, S.-L., Chen, D.-
S., et al. (2008). Associations Between Hepatitis B Virus Genotype and Mutants and the Risk of Hepatocellular Carcinoma. Journal of the National Cancer Institute 100, 1134-1143.

Yang, W., and Summers, J. (1995). Illegitimate replication of linear hepadnavirus DNA through nonhomologous recombination. Journal of Virology 69, 4029-4036.

Yu, H., Yuan, Q., Ge, S.-X., Wang, H.-Y., Zhang, Y.-L., Chen, Q.-R., Zhang, J., Chen, P.-J., and Xia, N.-S. (2010). Molecular and phylogenetic analyses suggest an additional hepatitis B virus genotype "I". PLoS ONE 5, e9297.

Zheng, X., Weinberger, K.M., Gehrke, R., Isogawa, M., Hilken, G., Kemper, T., Xu, Y., Yang, D., Jilg, W., and Roggendorf, M. (2004). Mutant hepatitis B virus surface antigens ( $\mathrm{HBsAg})$ are immunogenic but may have a changed specificity. Virology 329, 454-464. 


\section{Further Reading}

Caister Academic Press is a leading academic publisher of advanced texts in microbiology, molecular biology and medical research. Full details of all our publications at caister.com

- MALDI-TOF Mass Spectrometry in Microbiology Edited by: M Kostrzewa, S Schubert (2016) www.caister.com/malditof

- Aspergillus and Penicillium in the Post-genomic Era Edited by: RP Vries, IB Gelber, MR Andersen (2016) www.caister.com/aspergillus2

- The Bacteriocins: Current Knowledge and Future Prospects Edited by: RL Dorit, SM Roy, MA Riley (2016)

www.caister.com/bacteriocins

- Omics in Plant Disease Resistance Edited by: V Bhadauria (2016) www.caister.com/opd

- Acidophiles: Life in Extremely Acidic Environments Edited by: R Quatrini, DB Johnson (2016) www.caister.com/acidophiles

- Climate Change and Microbial Ecology: Current Research and Future Trend

Edited by: J Marxsen (2016)

www.caister.com/climate

- Biofilms in Bioremediation: Current Research and Emerging Technologies

Edited by: G Lear (2016)

www.caister.com/biorem

- Microalgae: Current Research and Applications Edited by: MN Tsaloglou (2016) www.caister.com/microalgae

- Gas Plasma Sterilization in Microbiology: Theory, Applications, Pitfalls and New Perspectives Edited by: H Shintani, A Sakudo (2016) www.caister.com/gasplasma

- Virus Evolution: Current Research and Future Directions Edited by: SC Weaver, M Denison, M Roossinck, et al. (2016) www.caister.com/virusevol

- Arboviruses: Molecular Biology, Evolution and Control Edited by: N Vasilakis, DJ Gubler (2016) www.caister.com/arbo

- Shigella: Molecular and Cellular Biology Edited by: WD Picking, WL Picking (2016) www.caister.com/shigella

-Aquatic Biofilms: Ecology, Water Quality and Wastewater Treatment

Edited by: AM Romaní, H Guasch, MD Balaguer (2016)

www.caister.com/aquaticbiofilms

- Alphaviruses: Current Biology

Edited by: S Mahalingam, L Herrero, B Herring (2016)

www.caister.com/alpha

- Thermophilic Microorganisms

Edited by: F Li (2015)

www.caister.com/thermophile
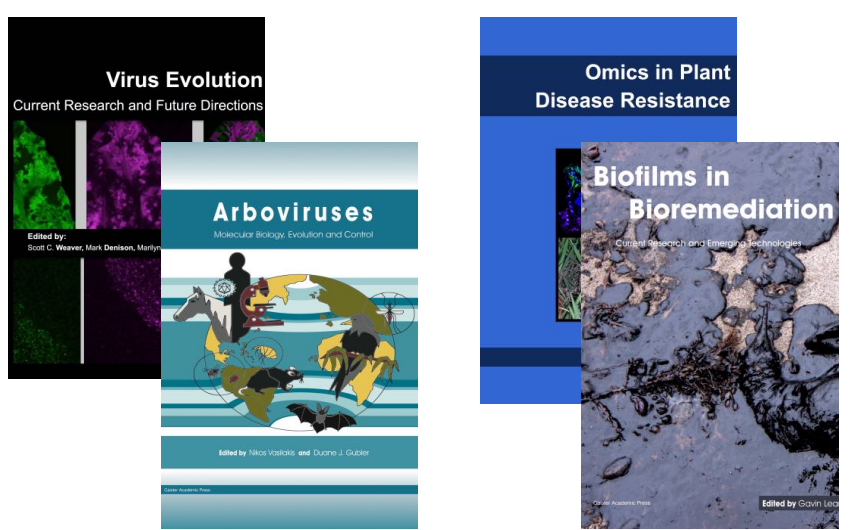
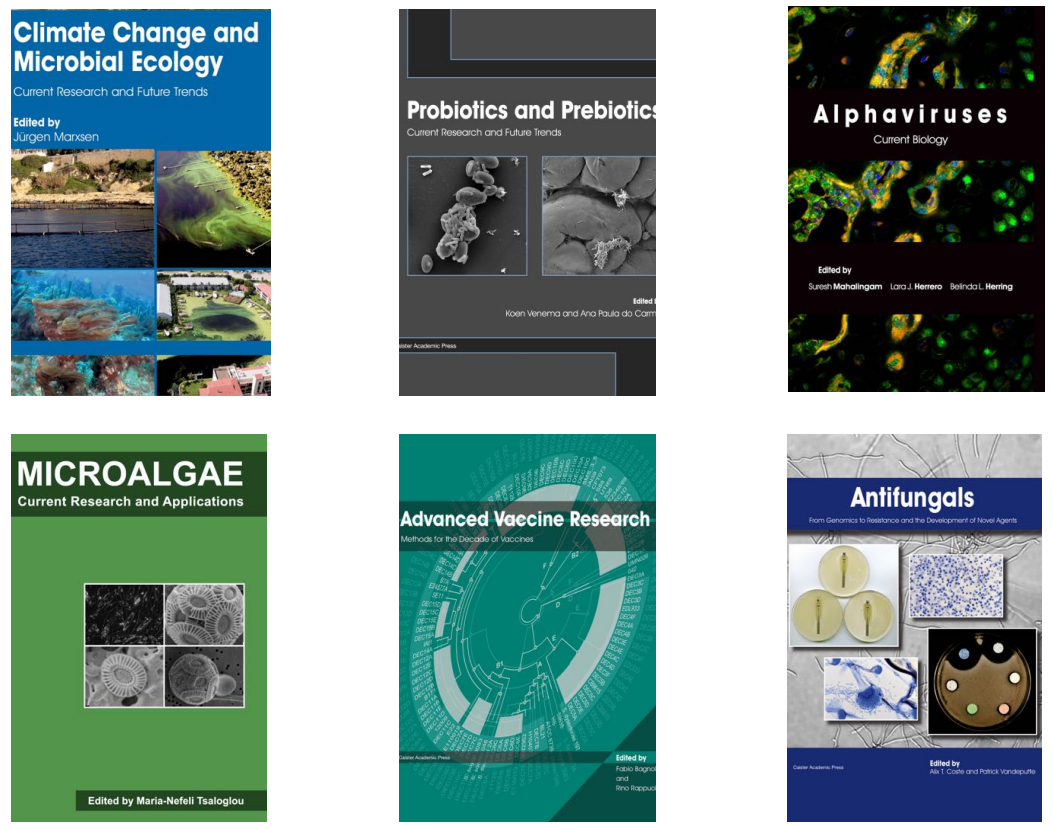

- Flow Cytometry in Microbiology: Technology and Applications Edited by: MG Wilkinson (2015) www.caister.com/flow

- Probiotics and Prebiotics: Current Research and Future Trends Edited by: K Venema, AP Carmo (2015) www.caister.com/probiotics

- Epigenetics: Current Research and Emerging Trends Edited by: BP Chadwick (2015) www.caister.com/epigenetics2015

- Corynebacterium glutamicum: From Systems Biology to Biotechnological Applications

Edited by: A Burkovski (2015)

www.caister.com/cory2

- Advanced Vaccine Research Methods for the Decade of Vaccines

Edited by: F Bagnoli, R Rappuoli (2015)

www.caister.com/vaccines

- Antifungals: From Genomics to Resistance and the Development of Novel Agents

Edited by: AT Coste, P Vandeputte (2015)

www.caister.com/antifungals

- Bacteria-Plant Interactions: Advanced Research and Future Trends Edited by: J Murillo, BA Vinatzer, RW Jackson, et al. (2015) www.caister.com/bacteria-plant

\section{- Aeromonas}

Edited by: J Graf (2015)

www.caister.com/aeromonas

- Antibiotics: Current Innovations and Future Trends

Edited by: S Sánchez, AL Demain (2015)

www.caister.com/antibiotics

- Leishmania: Current Biology and Contro Edited by: S Adak, R Datta (2015) www.caister.com/leish2

- Acanthamoeba: Biology and Pathogenesis (2nd edition) Author: NA Khan (2015)

www.caister.com/acanthamoeba2

- Microarrays: Current Technology, Innovations and Applications Edited by: Z He (2014)

www.caister.com/microarrays2

- Metagenomics of the Microbial Nitrogen Cycle: Theory, Methods and Applications

Edited by: D Marco (2014)

www.caister.com/n2 